\title{
Engineering Center as a tool for HEl's scientific and innovation potential integration in the real economy
}

\author{
M.S. Minkin ${ }^{1, *}, M . A$. Izotov $^{1}$, and $O . G$. Ananova $^{1}$ \\ ${ }^{1}$ Don State Technical University, Rostov-on-Don, Russia
}

\begin{abstract}
Currently, one of the biggest challenges facing the state HEI is the problem for commercialization of intellectual activity results using technology transfer funds into the real economy. However, if the creating products processes ends in Research and Development stage, everything is quite transparent and clear here, but at the stage of transition to the process of self-production and sales there appears a number of difficult problems solvable. To simplify the interaction between the university and the enterprises of the real economy are invited to create an engineering center as a separate entity, affiliated with the university, whose tasks will include the issues of technology transfer to the real economy, as well as the establishment of an external production site, to address the commercialization of tasks results of intellectual activity without involving in this process the intermediate third-party organizations.
\end{abstract}

\section{Introduction}

Innovative activity and small business - two main components of a sustainable development of modern economy. The market relations assume existence of the enterprises of various sizes and forms of ownership. It is necessary to allocate especially small forms of the enterprises for implementation of innovative activity as small enterprises differ in high efficiency in decisionmaking, fast adaptation to influences of external factors, high turnover of means and small management expenses, and also a susceptibility to innovations in production and administrative activity.

Small business in the innovative sphere is the most important structural element of new economic business models and a nutrient medium for system changes in technology and the social relations. The small innovative enterprises in the person of their most dynamic and successful representatives act for economy, on the one hand, as the test business ground, and with another - the excellent base on which the national and global companies are under construction.

It is very important that the priority directions of formation of innovative infrastructure, mechanisms of support of the small innovative enterprises and investment projects of their development became key contents of regional programs of support of development of small innovative business. A main objective of the small innovative enterprise as commercial organization, receiving profit on the basis of introduction of scientific developments in production and production is. Unfortunately, now not all enterprises are ready to introduction of results of innovative activity because of high cost of cost of the new equipment, materials, increase in costs of a salary to new qualified personnel and other reasons. Many enterprises now, seeking for maximizing profit, go on the way of reduction of product cost due to decrease in her quality, and it often leads to decrease in demand for products.

According to the Federal Law of August 2, 2009 № 217-FL "On making amendments to some legislative acts of the Russian Federation concerning the process of establishment by budget scientific and educational institutions the business entities to practical implementation of intellectual activity results" the budgetary scientific institutions, and also the created scientific institutions, have the right to be founders of economic societies, in particular the small innovative enterprises for the purpose of practical application of results of intellectual activity (programs for electronic computers, databases, inventions, useful models, industrial samples, selection achievements, etc.), exclusive rights to which belong to these scientific institutions.

Creating of the engineering center as a separate legal entity, affiliated with HEI can become a successful mechanism for commercialization of scientific and innovative potential of state HEIs. The proposed organizational and legal form of the commercial organization will be Limited Liability Company. It will be registered in accordance with the Federal Law of the Russian Federation (Federal Law of August 2, 2009 № 217-FZ "On making amendments to some legislative acts of the Russian Federation concerning the process of establishment by budget scientific and educational institutions the business entities to practical implementation of intellectual activity results"), according to which the budgetary scientific institutions and universities, which are budgetary educational institutions were granted the right to create, together with other legal

*Corresponding author:msi_58@mail.ru 
entities or individuals economic companies without having the special consent from the federal enforcement authorities, which they are administered by. This law opened up the new opportunities to increase the efficiency of the higher education interaction with high-tech sector to increase competitiveness of the economy.

The business profile of such entities' economic activity is a practical application (implementation) of the intellectual activities results (RIA), which exclusive rights belong to this budget institution. The RIA selection is carried out by institution independently on the database analysis results accounting RID of this budget institution and the results of market needs investigations for the planned areas of practical application (implementation) RID.

The business entity that is planned to create is a subject to state registration in accordance with the Federal Law of 8 August 2001 (Ed. July 21, 2014) № 129-FZ "On the State Registration of Legal Entities and Individual Entrepreneurs".

The main advantage of this business entities created under the Federal Law of August 2, 2009 № 217-FZ is a possibility to apply the simplified taxation system, as well as the minimization of insurance premiums deductions during the wages paymentf. The Federal Law №272-FZ of 16.10.2010 sets for the business entities applying the simplified taxation system the total size of insurance premiums in the amount of $28.2 \%$.

The educational institution, being the participant of economic community, is engaged in activities to support them. These activities may take the concluding the research and development agreements; providing the innovative services infrastructure; attracting the employees to work part-time in business companies; HEI's departments and divisions hardware and software.

\section{The analysis of project risks}

As an example we should consider the creation of the agricultural engineering center project.

Engineering Centre is created at the junction of two industries: agricultural machinery (technological equipment for the compound feed industry) and industrial biotechnology (production of industrial enzymes and microorganisms). The total project cost is 104 million. rub., at their own expense.

To confirm the effectiveness of the described systems we shall carry out the project risks calculation.

One admits to share the qualitative and quantitative analysis of project risks. One of the most common quantitative analysis methods is to analyze the sensitivity of the project, in other words to study how the project effectiveness will change depending on changes in any parameter. The sensibility analysis of the investment project is to assess the impact of the changes in any single project option to the project performance indicators, provided that the other parameters remain unchanged. The account must be taken that the project is more sensitive to the parameter's changes, the higher the risk and the more significant the parameter will be reflected in the risk reduction activities.

The main factors for the resulting test sensibility analysis are:

- prices of products (sales volume);

- the level of unit costs;

- the size of the investment costs.

These parameters' changes are carried out in the design model at 10, 20 and $30 \%$ both in the direction of increasing and decreasing values. At the same time as a final indicator of the project the net present value (NPV) is considered, due to the fact that this very one indicator is the feasibility indicator of the innovative project. The sensibility analysis results are shown in the table and in the graph.

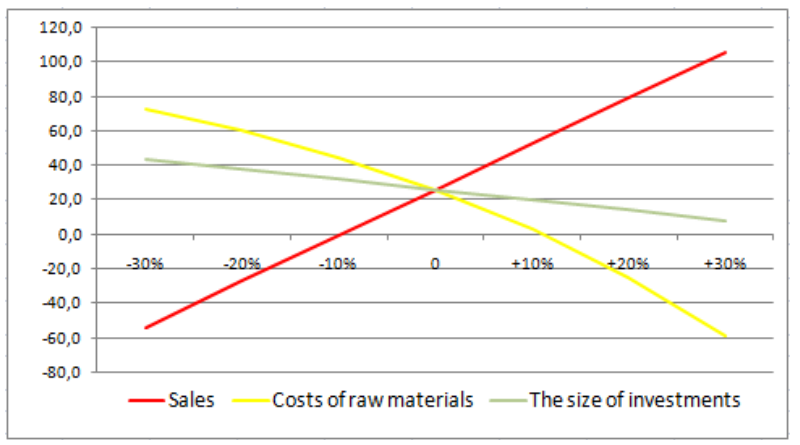

Fig. 1. Net Present Value of the project less the amount of subsidies.

The project is more sensitive to price fluctuations for raw materials: an increase of a factor of $20 \%$ leads to the formation of a negative net present value (NPV) of the project in the period under consideration. However, the risks associated with this factor are regulated by the registered character of the engineering center services and the specifics of the raw materials list drawing up (engineering center being a solution developer has the ability to pick up raw materials from the point of view of economic expediency of a specific contract), as well as the fact that the inflationary processes' impact on the budgeting of the materials and supplies costs are provided by this financial model originally.

Table 1. Net Present Value (NPV) of the project.

\begin{tabular}{|c|c|c|c|c|c|c|c|}
\hline \multirow{2}{*}{ Parameter } & \multicolumn{7}{|c|}{ Net Present Value (NPV) of the project, mln. Rub. } \\
\cline { 2 - 8 } & $-30 \%$ & $-20 \%$ & $-10 \%$ & 0 & $+10 \%$ & $+20 \%$ & $+30 \%$ \\
\hline Sales (sales price) & -54.1 & -27.4 & -0.8 & 25.8 & 52.4 & 79.0 & 105.6 \\
\hline Costs of raw materials & 72.3 & 60.0 & 44.7 & 25.8 & 2.6 & -25.4 & -59.1 \\
\hline Investments size & 43.7 & 37.7 & 31.8 & 25.8 & 19.8 & 13.9 & 7.9 \\
\hline
\end{tabular}

The maximum sensibility of the project demonstrates the value of sales (sale price). On reducing of this parameter to $10 \%$ of the project net present value (NPV) becomes zero in the period of 4 years 3 months. However, the actual risk of such 
changes is small due to the number of factors: the virtual absence of direct competition, the availability of stakeholders, integrated approach to the services provision, as well as their wide range, combined with the presence of the work plan for the promotion of products in the industry and assessment of prospective sales market in the absence of direct analogs.

In order to assess the degree of the most risky settings impact on the actual Engineering Centre cash flows it is advisable to analyze the sensibility of the project to their vibrations, using as a final value of the engineering center net profit index after reaching its design capacity.

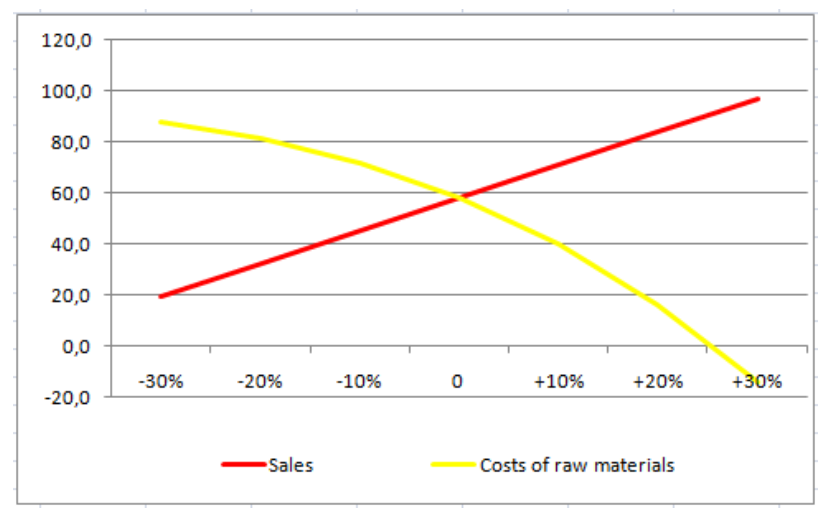

Fig. 2. Net Present Value of the project.

This one-parametric sensibility analysis of the project net profit value to the changes in sales and costs rates and materials shows the high stability of the basic

economic indicators (net profit) to the changes in sales and selling prices of the services. With $30 \%$ deviation of this factor from the planned value engineering center will remain profitable. Decline in net profit will amount to $67 \%$ (from $58.1 \mathrm{mln}$. Rub. To $19.2 \mathrm{mln}$. Rub.). This indicates a high degree of the project financial stability.

In order to analyze the project financial stability it is advisable to determine the breakeven point, that is one of the most important landmarks of the project risk assessment. This type of analysis shows the principle feasibility of the project in terms of achieving the set profit value. Breakeven point characterizes the situation when total revenues will be equal to total costs. Calculation of breakeven point has been made in the planning interval after reaching its design capacity.

The table show the breakeven point when you change the volume being provided by the Engineering services center:

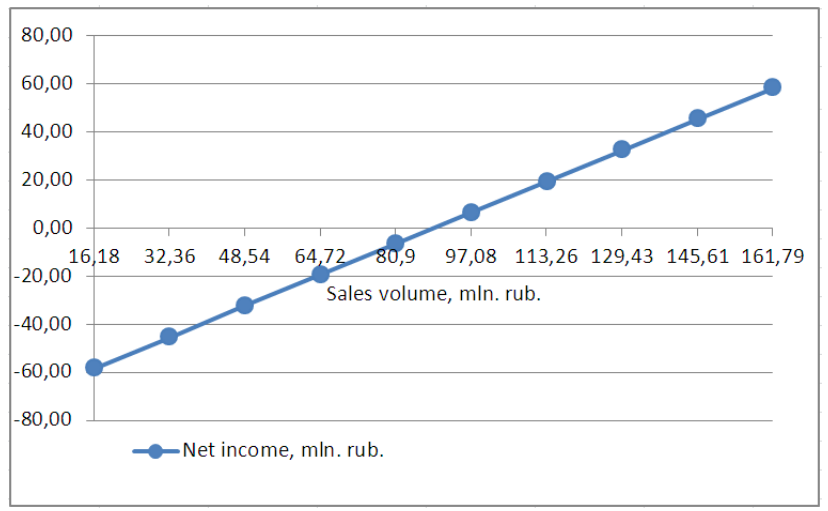

Fig. 3. Net Present Value of the project less the amount of subsidies.

At the rate of breakeven point, it follows that the situation comes on the sales of 89.22 million rubles. per year $(55.1 \%)$ from the planned value when Engineering Center's revenues are equal to expenses. It follows that even if there is the decrease in the volume of services by more than $40 \%$ of the forecast, the Engineering Center will be self-financing.

Thus, the main project risk factor is the size of the raw materials costs. The methods for risk factors control and reduction planned for implementation during the project are:

- Cost accounting is an introduction and continuous development of the cost accounting systems for the provision of services in accordance with a few basic techniques: documentation, inventory, permanent evaluation;

Table 2. The net profit of the project.

\begin{tabular}{|c|c|c|c|c|c|c|c|}
\hline \multirow{2}{*}{ Parameter } & \multicolumn{7}{|c|}{ The net profit of the project, mln. rub. } \\
\cline { 2 - 8 } & $-30 \%$ & $-20 \%$ & $-10 \%$ & 0 & $+10 \%$ & $+20 \%$ & $+30 \%$ \\
\hline Sales (sales price) & 19.2 & 32.2 & 45.1 & 58.1 & 71.0 & 83.9 & 96.9 \\
\hline Costs of raw materials & 87.6 & 81.0 & 71.4 & 58.1 & 40.0 & 16.4 & -14.0 \\
\hline
\end{tabular}

Table 3. The breakeven point.

\begin{tabular}{|c|c|c|c|c|c|}
\hline Parameter & $\mathbf{1 0} \%$ & $\mathbf{2 0} \%$ & $\mathbf{3 0} \%$ & $\mathbf{4 0 \%}$ & $\mathbf{5 0 \%}$ \\
\hline Sales volume, mln. per year & 16.18 & 32.36 & 48.54 & 64.72 & 80.9 \\
\hline Net income, mln. rub. & -58.43 & -45.49 & -32.54 & -19.60 & -6.66 \\
\hline Parameter & $\mathbf{6 0} \%$ & $\mathbf{7 0} \%$ & $\mathbf{8 0} \%$ & $\mathbf{9 0 \%}$ & $\mathbf{1 0 0} \%$ \\
\hline Sales volume, mln. per year & 97.08 & 113.26 & 129.43 & 145.61 & 161.79 \\
\hline Net income, mln. rub. & 6.29 & 19.23 & 32.18 & 45.12 & 58.06 \\
\hline
\end{tabular}


- Centralized control of pricing and established planned targets, in terms of the cost of services rendered;

- The use of resource-saving, low-waste and nonwaste technologies;

- Strengthening of individual and collective responsibility, and material interest in the sustainable resource management;

- Material costs rationing.

\section{Risk assessment out of the formal analysis}

The risks that emerge in the implementation stage of capital investments are:

- failure to fulfill obligations by the supplier (low quality, defects in equipment, technology);

- untimely delivery and equipment installation of;

- the incompatibility of domestic equipment imported;

- the failure of the timing of construction;

- the excess of the estimated project cost;

- force majeure, damage to property.

The risk of the equipment suppliers' default from the obligations can be characterized as "low"; the technological scheme of the production planned for the engineering centers, involves the use of the adapted and widespread equipment. The market suppliers of this equipment are quite enough to make a choice of high quality.

The risks of force majeure and property damage also are assessed as "low". This conclusion leads to the stability of the economic and geopolitical situation in Russia, as well as the fact that the placement of the region and the activities of companies are characterized by the absence of any climatic threats.

Risks associated with the operation of the enterprise are:

- not reaching the design capacity (the emergence of technological constraints or raw);

- the products do not sell well in the desired value and settlement periods (the emergence of price caps, the revaluation or underestimation of the market competition in the marketing);

- inflation costs (faster growth of prices for raw materials, energy and other costs of the article.)

- untimely supply of raw materials.

The availability of pre-interest of several potential customers, a wide and diverse range of the services, the virtual absence of equivalent competitors in the market and growing the industry market will reduce the risks associated with the possible absenteeism at full capacity.

Sufficient random of raw material's suppliers for production services as well as the nature of services, most of which is a product of intellectual work, allow us reckon on a high viability of the project without dependence on one particular supplier of raw materials. The sensibility analysis had demonstrated the importance of the raw materials prices that would be taken into account in Engineering Center's activities.

Pricing Policy of the considered project and integrated approach to the service package formation leave the stock "price leverage" to promote a competitive offer products on the market under consideration and control the of the negative impact of inflation.

\section{Conclusion}

The calculations show a high resistance to changes in project size of investment costs: even with the increase of this factor within the project net present value (NPV) remains positive in a period of 4 years and 3 months. This is due to the relatively short investment period, as well as high levels of economic efficiency of the project.

\section{References}

1. E.S. Klimovich, Accounting in budget and nonprofit organizations, 21 (2006)

2. N.V. Novozhilov, Bulletin of CSU, 4 (2007)

3. T.M. Bezborodova, K.N. Poladenko, STAGE, 2(20) (2015)

4. A.V. Palashenkov, Bulletin of Omsk State University. Series. Right, 4 (2011)

5. L.A. Bakhvalov, D.A. Zhuravlev, PROC, 2-1 (2008)

6. Z.I. Abdullaev, Wax, 9(57) (2013)

7. A.M. Polinsky, SR, 1 (2014)

8. W.J. Shalbolov, M.A. Albanova, L.A. Kazbekov, Physics of fluids. Series: Economics and law, 10(44) (2014)

9. V.V. Shmat, I.A. Lutkov, Economics and modern management: theory and practice, 38 (2014)

10. I.U. Chekmazov, E.V. Iodine, Socio-economic phenomena and processes, 9, (2014).

11. V.N. Arslanov, I.S. Gazizov, N.G. Kashapov, R.A. Celbraties, V.V. Khomenko, E.V. Shamsutdinov, Z.G. Shigapov, MAPS, 4 (2014)

12. V.V. Pod'yapolskii, MAPS, 2 (2015)

13. S.A. Tikhonova, Science. Innovation. Education, 9, (2010)

14. O.A. Saprykin, Innovations, 3 (2008)

15. E.S. Taushev and N.I.Smorodinova, Actual problems of aviation and cosmonautics, 8 (2012)

16. O.V. Puchkova, R.M. Shigapov, Economics and modern management: theory and practice, $4(48-1)$ (2015)

17. I.K. Novikova, A.V. Polutornyi, I.A. Ivanov, GORN, 7 (2011)

18. A.A. Kozlov, Management of innovation: theory, methodology, practice, 1 (2012)

19. K.A. Maksimov, M.E. Bryleva, Journal of the science of Science, 3(16) (2013)

20. S.E. Aznauryan, A.A. Solonenko, Economics and business: theory and practice, $\mathbf{4},(2015)$

21. J.E. Amadi-Echendu, A. John, Proc. Portland International Conference on Management of Engineering \& Technology, Cape Town, 1491$1496(2008)$

22. S. Su, H.D. Wang, Proc. 2008 4th International Conference on Wireless Communications, Networking and Mobile Computing, 1-4 (2008)

23. Y.K. Zhai, Q.Q. Dong, Proc. 2007 International Conference on Wireless Communications, Networking and Mobile Computing, Shanghai, 6305-6308 (2007)

24. Z. Ke-ying, L. Ruixia, Proc. 2009 International Conference on Information Management, Innovation Management and Industrial Engineering, 141-145 (2009)

25. H. Feng, Proc. Management and Service Science (MASS), Wuhan, 1-3 (2010) 